\title{
Assessing the effects of e-wallet scheme in farm inputs distribution to rural farmers in Imo State, Nigeria
}

\author{
GODSON-IBEJI C.C ${ }^{1 *}$, CHIKAIRE, J.U ${ }^{1}$ and ANYAOHA N.O ${ }^{1}$ \\ ${ }^{1}$ Department of agricultural extension, school of agriculture and agricultural technology (saat), federal university of \\ technology, owerri (FUTO) Imo State Nigeria. \\ Accepted 30 June, 2016
}

The study assessed the effect of e-wallet scheme in farm input distribution to rural farmers in Imo state of Nigeria. The main objective of the study was to assess the effects of e-wallet scheme in farm input distribution to rural farmers in Imo state .One hundred and eighty farmers were randomly selected from the three agricultural zones of Imo state with a multistage sampling technique. Data were analyzed by the use of descriptive statistical tools such as frequency distribution, percentages. The results from the study revealed that most of the farmers who benefited from the scheme were mostly young male farmers between the ages of 41-50 years with a mean of 45.5 years. They are also married with large mean household size of $(M=10)$ persons but low educational status. The study also revealed that the benefits from the scheme included: quick accessibility of improved and subsidized farm inputs, increased production and resuscitation of farmers' confidence in government programmes. The challenges faced by the farmers included; telephone network failures, incompatibility of e-wallet with other technologies, low density coverage of agro dealers among others. The study concludes that there is need to enhance the productive capacity of rural farmers in Imo state so as to meet up with food security of the nation. The study recommends among others the improvement of rural telephone networking for improved interconnectivity between the helpline staff and the cellulants, also the scaling up of the quantity of input supply by the government to accelerate and increase the production capacity of the rural farmers in Imo state of Nigeria. Increasing productivity means ensuring food supply and food security.

KEYWORDS: E-Wallet, Rural farmers, inputs distribution and effects.

\section{INTRODUCTION}

Agriculture has been the mainstay of Nigerian economy for several years and is till contributing significantly to the Gross Domestic Product (GDP) of the country (Patachu, 2014). According to the National Bureau of Statistics (2012), agriculture has the potentials for employment generation, food security and poverty reduction in Nigeria. This potential however remained untapped over the years. Agriculture production in Imo state is mainly carried out by farmers in rural areas. Most of the farmers are fragmented, having low input and output.

The usage of farm machines, fertilizers and improved seeds has been very low. The South Western zone of the country was renowned mainly for its cocoa production, the proceeds of which were used to build the prestigious

\footnotetext{
*Corresponding authors E mail: comfortgodsonibeji@yahoo.com
}

Obafemi Awolowo University and the Cocoa House in Ibadan. The South Eastern and South South zones of the country were renowned for their oil palm production, while the Northern part of Nigeria was renowned for its groundnut and cotton production. Nigeria was one of the largest exporters of agricultural produce of oil palm and cocoa until the discovery of crude oil which resulted in the partial neglect of its agricultural sector.

Even with the decline in the agricultural sector, agriculture continued to contribute about $40 \%$ to Nigeria's GDP in 2010 - 2011 (based on NBS Nigeria Economic Outlook 2012 Report). Agriculture is predominantly practiced in the rural areas of the country hence, there is need to ensure that farmers in the rural areas get access to farm inputs such as fertilizers, seeds and information to enhance their productivity.

In view of this, in July 2012, the Federal government introduced the Growth Enhanced Support Scheme 
(GESS) which is designed to deliver government subsidized farm inputs directly to farmers via GSM phones. The GESS is powered by e-wallet, an electronic distribution channel which provides an efficient and transparent system for the purchase and distribution of agricultural inputs based on a voucher system. The scheme guarantees registered farmers e-wallet with which they can redeem fertilizers, seeds and other agricultural input from agro-dealers at half the cost, the other half being borne by the federal government and state government in equal proportions. An E-wallet is defined as an efficient and transparent electronic device system that makes use of vouchers for the purpose and distribution of agricultural inputs (Ezeh 2013, Adesina, 2013).

The E-wallet system was introduced as a pilot project in 36 states and the federal capital territory. E-wallet was launched in Imo state in July 2012 with redemption centres in each of the 27 local government areas in the state.

About 250,000 farmers have registered for the system and have been obtaining fertilizer. So far, about 230,000 farmers have reportedly benefited from the system. The E-wallet system which is controlled by the state ministry of agriculture has been able to distribute a larger amount of fertilizer throughout the state between 2012-2014.

\section{Statement of the problem}

Fertilizer procurement and distribution in the country has been fraught with fraud, discrepancies and inefficiencies. Government at the federal and state levels were spending a lot of money on farm inputs which were not reaching the intended beneficiaries (mostly small holder farmers) and thus, had no impact on the national food output. The federal government was involved in the direct procurement and distribution of fertilizers and this weakened the ability of private companies to participate in the sector and complete efficiently for market share. As with most subsidy regimes, the sector was grossly under developed and the opportunities for fraud and diversion were rampant.

This procurement and distribution of fertilizer has grossly affected farmers productivity and income. To ascertain the broad effectiveness of the scheme, the researcher presents the following research questions:

$>$ What are the socio-economic characteristics of the respondents?

$>$ Are the small scale farmers involved in the ewallet scheme?

$>$ What are the inputs distributed?

$>$ Are the inputs distributed to meet the cropping season at the right time?

$>$ What effort has the inputs on their productivity?

$>$ Do the small scale farmers face any challenges in the use of e-wallet system? If yes, what are the problems?

$>$ How can the challenges be addressed to prevent future occurrence?

\section{Objectives of the study}

The broad objective of this study is to determine the socio-economic effectiveness of e-wallet distribution in Imo state, while the specific objectives of the study were;

$>$ to identify the socio-economic characteristics of the respondents,

$>$ to determine the level of awareness of the scheme,

$>$ to determine the various sources of information of the scheme in the study area,

$>$ to determine the level of usage of the e-wallet by the respondents,

$>$ to ascertain the benefits derived from the e-wallet approach in the study area,

$>$ to identify the constraints or challenges of the ewallet approach to the farmers in the study area and,

$>$ to identify ways of addressing the challenges.

\section{METHODOLOGY}

The study area was Imo state of Nigeria .The state is located in the South Eastern region of Nigeria with Owerri as its capital city. Imo state lies within latitude $40^{\circ}$ $25^{\circ} \mathrm{Nand} 70^{\circ} 15^{\prime} \mathrm{N}$ and longitude $60^{\circ} 50^{\circ} \mathrm{E}$ and $70^{\circ} 25^{\circ} \mathrm{E}$ and cover an area of around $5,150 \mathrm{sqkm}$. It is bounded by Abia State on the East and Delta State on the west, Anambra State to the North and River State to the South. The state has 3 agricultural zone which are Orlu, Okigwe and Owerri zones with 27 local Government areas. The State has a population of 4,904,899 people in 2015 projected from 2006 census figure.

The climate of the area is fairly constant, with the raining season beginning in April and lasting until October with annual rainfall varying from $1500 \mathrm{~mm}$ to $21200 \mathrm{~mm}$ (60 to 80 inches).An average annual temperature above $20^{\circ} \mathrm{C}(68 \mathrm{~F})$ creates annual relative humidity of $75 \%$ with humidity reaching $90 \%$ in the raining season. The dry season experiences two months of harmattan from late December to late February. The hottest months are between Januarys and march. Agriculture is the main or dominant occupation. Igbo and English are the major languages spoken in the state.

A multi-stage sampling technique was used in selecting the respondents utilized for the study. This was based on the Imo state Agricultural Development Project (IMOADP) zonal system. The first stage involves a random selection of two out of three ADP zones which is 
Owerri and Orlu zones. The second stage involves a random selection of two local government areas from each zone making a total of four LGA's which are Owerri West and Ezinihtte Mbaise from Owerri zone, Ideato North and Orlu from Orlu zone. The third stage involves a random selection of two communities from each local government area, making a total of eight communities. The last stage involves a random selection of twenty-five farmers who participated in the e-wallet project from each community. This gives a total of 200 respondents for the study.

Data for this study were collected using a structured questionnaire. A total of 200 copies of the questionnaire were distributed to the respondents. Objective 1,2,3,4,5,6 and 7 were analyzed using descriptive statistics such as frequency means and percentages. The percentages for the variables in the study will be calculated by dividing the number of responses to each question by the total respondents and multiplying by 100 . This gives the total percentage for each variable.

\section{Awareness of e-wallet}

Data in table 2 shows that 100 percent of the respondents were aware of the e-wallet approach. This means that the knowledge about e-wallet was well spread.

\section{Sources of information}

Table 3 shows their sources of information which varies, about $80.0 \%$ indicated that they got their information from ADP and extension agents. $57.5 \%$ via radio, $52.5 \%$ through farmer's meeting, $40.0 \%$ through co-operative societies, $18.0 \%$ through the television while $4.5 \%$ reads from the newspaper. It could be said that interpersonal communication is the major sources of information to the farmers in the study area.

Apart from radio, all other media of communication recorded low percentages; this might be due to several reasons some of which might be their low educational status. Iow accessibility and affordability of other sources of information. Most of them live in remote village where facility such as the internet is not available. In addition, most of these factors might be influenced by their income level. The higher the income levels of farmers, the greater the ability to meet other family needs outside the basic needs of food, shelter and clothing.

\section{Level of e-wallet usage}

Table 4 shows that $96.0 \%$ of the respondents possess mobile phones while $4.0 \%$ did not. Personal interaction with the few that did not have mobile phone revealed that they utilize their children's phone in receiving information on e-wallet. Hence it could be said that all the respondents possess mobile phones. Also all of them registered with the growth enhancement programme. The dates of registration vary with the majority $(64.0 \%)$ registering in 2012 while $36.0 \%$ registered in 2011 . Also, all of them attended the e-wallet training organized for them.

A huge proportion $(82.5 \%)$ of the respondents did not benefit from any agricultural innovation/production intervention before the e-wallet approach. From the GES, $53.5 \%$ of the respondents benefited from the subsidized improved maize seed. $51.0 \%$ benefited from subsidized improved rice seed while $87.5 \%$ got fertilizer at a subsidized rate. $20 \mathrm{~kg}$ of improved seed of maize and rice as well as 2bags of fertilizer were given to each of the participant of the scheme. The few $(5.0 \%)$ respondents that could not get the fertilizers indicated some challenges in the process of linkage with the fertilizer dealers.

Most of the respondents (52.5\%) have benefited twice, $20.0 \%$ have benefited thrice, while $32.5 \%$ benefited once. The number of times the participants benefited from the program is expected to increase as the government tries to perfect the system.

\section{Benefits derived from using in e-wallet system}

Data in table 4.5 indicated the benefits derived from participating in e-wallet approach by the farmers as follows; quickened accessibility to improved seed $(80.0 \%)$, access to fertilizer $(87.5 \%)$, and subsidized farm input $(97.5 \%)$ and renewed confidence in government programmes $(67.5 \%)$. It was indicated that participation in e-wallet led to increased output (90.0\%) and increased quality of maize/rice production by $67.0 \%$ of the respondents. Only $10 \%$ of the respondents indicated that participation in e-wallet actually increase their farm size. This is line with IFPR (2010) report that access to subsidized seeds and fertilizer by small holder producers through the use of a voucher system transformed the food aid dependent economy of Malawi to an exporter of food. It is believed that if the e-wallet approach is sustained in Nigeria, it will go a long way in transforming the Nigerian economy too.

\section{Challenges of e-wallet approach}

\section{RESULTS AND DISCUSSION}

\section{Socio-economic characteristics of the respondents}

Data in table 1 shows the socio economic characteristics 
Table 1: Socio-economic characteristics of the respondents

\begin{tabular}{|c|c|c|}
\hline Variables Age (in years) & Frequency (200) & Percentage (100) \\
\hline $\begin{array}{l}<30 \\
31-40 \\
41-50 \\
51-60 \\
>60 \\
\end{array}$ & $\begin{array}{l}25 \\
45 \\
72 \\
39 \\
28 \\
\end{array}$ & $\begin{array}{l}12.5 \\
22.5 \\
36.0 \\
15 \\
14.0 \\
\end{array}$ \\
\hline \multicolumn{3}{|l|}{ Sex } \\
\hline $\begin{array}{l}\text { Male } \\
\text { Female }\end{array}$ & $\begin{array}{l}165 \\
35 \\
\end{array}$ & $\begin{array}{l}82.5 \\
17.5\end{array}$ \\
\hline \multicolumn{3}{|l|}{ Marital status } \\
\hline $\begin{array}{l}\text { Single } \\
\text { Married } \\
\text { Separated/Divorced } \\
\text { Widowed } \\
\end{array}$ & $\begin{array}{l}10 \\
105 \\
30 \\
22 \\
\end{array}$ & $\begin{array}{l}5 \\
52.5 \\
15 \\
11 \\
\end{array}$ \\
\hline \multicolumn{3}{|l|}{ Household head } \\
\hline $\begin{array}{l}\text { Male headed household } \\
\text { Female headed household }\end{array}$ & $\begin{array}{l}172 \\
28\end{array}$ & $\begin{array}{l}86 \\
14\end{array}$ \\
\hline \multicolumn{3}{|l|}{ Highest level of education } \\
\hline $\begin{array}{l}\text { No formal education } \\
\text { Primary school completed } \\
\text { Junior secondary school completed } \\
\text { Senior secondary school completed } \\
\text { Tertiary education completed }\end{array}$ & $\begin{array}{l}97 \\
30 \\
45 \\
28 \\
45 \\
\end{array}$ & $\begin{array}{l}48.5 \\
15 \\
22.5 \\
14 \\
22.5 \\
\end{array}$ \\
\hline \multicolumn{3}{|l|}{ Primary occupation } \\
\hline $\begin{array}{l}\text { Farming } \\
\text { Trading } \\
\text { Hair dressing } \\
\text { Others } \\
\end{array}$ & $\begin{array}{l}22 \\
60 \\
20 \\
98\end{array}$ & $\begin{array}{l}11 \\
30 \\
10 \\
49 \\
\end{array}$ \\
\hline \multicolumn{3}{|l|}{ Type of land ownership } \\
\hline $\begin{array}{l}\text { Rented } \\
\text { Purchased } \\
\text { Leased }\end{array}$ & $\begin{array}{l}40 \\
20 \\
12\end{array}$ & $\begin{array}{l}20 \\
10 \\
6\end{array}$ \\
\hline \multicolumn{2}{|l|}{ Farm size } & 58 \\
\hline $\begin{array}{l}<500 \text { heaps } \\
501-2500\end{array}$ & $\begin{array}{l}13 \\
74\end{array}$ & $\begin{array}{l}6.5 \\
37\end{array}$ \\
\hline $\begin{array}{l}2501-5000 \\
5001-7000 \\
\end{array}$ & $\begin{array}{l}90 \\
4 \\
\end{array}$ & $\begin{array}{l}45 \\
2\end{array}$ \\
\hline \multicolumn{3}{|l|}{ Crop type } \\
\hline $\begin{array}{l}\text { Yam } \\
\text { Cocoyam }\end{array}$ & $\begin{array}{l}144 \\
65\end{array}$ & $\begin{array}{l}72 \\
32.5\end{array}$ \\
\hline $\begin{array}{l}\text { Plantain } \\
\text { Vegetable }\end{array}$ & $\begin{array}{l}105 \\
68\end{array}$ & $\begin{array}{l}52.5 \\
34\end{array}$ \\
\hline $\begin{array}{l}\text { Rice } \\
\text { Maize } \\
\text { Cassava }\end{array}$ & $\begin{array}{l}112 \\
125 \\
180\end{array}$ & $\begin{array}{l}56 \\
62.5 \\
90\end{array}$ \\
\hline \multicolumn{3}{|l|}{ Years of farming experience } \\
\hline $\begin{array}{l}<5 \text { years } \\
5-10 \text { years } \\
11-15 \text { years } \\
16-30 \text { years } \\
31-40 \text { years } \\
41-50 \text { years } \\
51 \text { years and above }\end{array}$ & $\begin{array}{l}15 \\
10 \\
94 \\
20 \\
16 \\
20 \\
25\end{array}$ & $\begin{array}{l}7.5 \\
5 \\
47 \\
10 \\
8 \\
10 \\
12.5 \\
\end{array}$ \\
\hline
\end{tabular}

Source: survey data, 2015. 
Table 2: awareness of e-wallet scheme

\begin{tabular}{lll}
\hline Variables & Frequency(200) & Percentage(100) \\
\hline Awareness of e-wallet scheme & & \\
Yes & 200 & 100 \\
No & 0 & 0 \\
\hline
\end{tabular}

Source: survey data, 2015

Table 3: sources of information

\begin{tabular}{lll}
\hline Variables & Frequency (200) & Percentage (100) \\
\hline Radio & 115 & 57.5 \\
Television & 36 & 18 \\
ADP agent & 160 & 80 \\
Newspaper & 9 & 4.5 \\
Farmers meeting & 105 & 52.5 \\
Cooperative societies & 80 & 40 \\
Internet & 0 & 0 \\
Friends & 65 & 32.5 \\
\hline
\end{tabular}

Source: survey data, 2015

Table4: level of e-wallet usage

\begin{tabular}{lll}
\hline Variables & Frequency (200) & Percentage (100) \\
\hline possession of mobile phones & 172 & 86 \\
\hline Yes & 28 & 14 \\
No & 200 & 100 \\
\hline Registration with GEP & 0 & 0 \\
\hline Yes & & 36 \\
No & 72 & 64 \\
\hline Date of registration & 128 & \\
\hline 2011 & 0 & 100 \\
2012 & & 0 \\
2013 & 200 & 22.5 \\
\hline Attendance of e-wallet training & 0 & 82.5 \\
\hline Yes & & 53.5 \\
No & 45 & 51 \\
\hline Previous benefit(s) from govt. program & 165 & 87 \\
\hline Yes & & \\
No & 107 & 32.5 \\
\hline Benefitted from GESS & 102 & 52.5 \\
\hline Improved seeds of maize (subsidized) & 175 & 20 \\
Fmprove seeds of rice (subsidized) & & \\
\hline Nortizer (subsidized) & 65 & \\
\hline One times of benefit from GESS & 105 & \\
Two times & 40 & \\
Three times & & \\
\hline
\end{tabular}

Source: survey data, 2015

Table 5: Benefits Derived From the Use of E-Wallet

\begin{tabular}{lll}
\hline VARIABLES & FREQUENCY (200) & PERCENTAGE(100) \\
\hline Quickened accessibility to improve seeds & 160 & 80.0 \\
Access to fertilizer distribution & 175 & 87.5 \\
Subsidized farm input, increased production & 185 & 92.5 \\
Renewed confidence in government program & 135 & 67.5 \\
Increased production & 180 & 90 \\
\hline
\end{tabular}

Source: survey data, 2015 
of the respondents. The age of the respondents ranged from 28-68 years with an average of 48.2 years. This indicates that most of the farmers that benefited from the e-wallet scheme are still young and are expected to be active in keying into the e-wallet approach and thus make effective utilization of the scheme to enhance their productivity.

More males than females got benefitted from the ewalle

t scheme. Large proportions $(52.5 \%)$ of the respondents were married, $16.5 \%$ were widowed and $11.0 \%$ were divorced or separated while $15.0 \%$ were co-habiting. Only a few $5.0 \%$ were single.

The high proportion of married people among the respondents is an indication of their responsibility and commitment in working to enhance their productivity. The household size for most of the respondents $(45 \%$ and $37.5 \%)$ ranged from 4-6 and 7-9 members respectively. About $13.5 \%$ has household size that is higher than 9 members. It could be said that most of the respondents have a large household size. The effect of a large household size is that a good proportion of the income of the household head will be diverted to meeting the basic needs of food, shelter and clothing.

About $86.0 \%$ of the respondents were male headed household while $14.0 \%$ were female headed households. Despite the fact that very few females benefited from the programme, but the larger proportion e male headed households. This has a lot of implication on the poverty level of the respondents due to the fact that female headed households in the developing economy faces challenges of access to land, credit facilities, improved farm tools and labor.

Indicators of the educational status show that $16 \%$ of the respondents have no formal education while $15 \%$ have below primary education, $22.5 \%$ completed primary six, $14.0 \%$ completed junior secondary school, $22.5 \%$ completed senior secondary school, while $10.0 \%$ have completed tertiary education. Although most of the farmers received one form of education or the other, a huge proportion $(67.5 \%)$ of them did not go beyond the junior secondary school. Since the information seeking ability and the amount of information received by an individual usually corresponds to his/her educational status. It could be said that most of the respondents have less access to information that could enhance their productivity. This may have a negative impact on their ability to manipulate and use the e-wallet approach effectively.

Result from the table also revealed that farming is the primary occupation of most of the respondents (91.0\%). With over $90 \%$ having more than 5 years farming experience confirms the fulfillment of one of the goals of the federal government on e-wallet approach. Several government interventions on agricultural production in Nigeria have been reported to side-line the farmers, thus defeating the aims of such interventions. The farming experiences gathered by the farmers could influence their abilities to make effective utilization of improved seeds and fertilizers.

The table also shows that $90,72.0,62.5,56.0,52.5$, 34.0 and $32.5 \%$ of the respondents plant cassava, yam, maize, rice, plantain, vegetable and cocoyam respectively. Most of the farmers planted more than one crop on the same farmland.

This is a special characteristic of most subsistence farmers of Nigeria. The source of land used for planting by most of the respondents (58\%) was through inheritance, $20.0 \%$ rented land and $10.0 \%$ purchased land while $6.0 \%$ got the land through lease.

The farm size of the respondents ranged from 480 heap (possessed by 6.5\%) to 501-2500 heaps (possessed by 3.8\%) and 2501-5000 heaps possessed by $45.0 \%$ of the respondents. It could be said that most of the farmers that benefited from the e-wallet approach are small scale farmers. This confirms the fact that the ewallet approach actually reached the target group, i.e. the small scale farmers.

Data in table 6 revealed the challenges of the e-wallet approach as well as the percentages of respondents indicating such challenges in order of magnitude as;

$>$ Low level of awareness by the farmers (56.0\%)

$>$ Insufficient fertilizer supply (52.0\%)

$>$ Cumbersome procedure of getting approval from cellulants (44\%)

$>$ Low density coverage of agro-dealers (32.5\%)

$>$ Poor telephony network $(43.5 \%)$ and

$>$ Insufficient seed supply (14.0\%)

$>$ Incompatibility of e-wallet with other technologies $(90 \%)$

$>$ Inability to operate mobile phone (40.5\%)

$>$ High rate of illiteracy $(63.5 \%)$

The low level of awareness by the farmers might result from the restricted sources of information being utilized by them the interpersonal communication. According to CGIAR (1997), Nigerian farmers seldom feel the impact of agricultural innovation either because they have no access to such vital information or because it is poorly disseminated. For approaches to agricultural development programme to work in Africa there is the need to take new approaches to information dissemination and management that grow out from a clear understanding of what farmers information needs are (CGIAR, 1997).

Insufficient fertilizer challenges actually occur as a result of failure on the part of agro dealers to order and supply fertilizer from the manufacturing company. This is contrary to the view of IFPR (2010) that the promotion of a dual fertilizer market (subsidized and free-market) has prevented the required response from the private sector in taking over the role played by the public sector. With the golden opportunity given to the private sector in the growth enhancement scheme, the problems of fertilizer 
Table 6: Challenges of E-Wallet Approach

\begin{tabular}{lll}
\hline Variables & Frequency (200) & Percentage (100) \\
\hline Insufficient fertilizer & 104 & 52.0 \\
Insufficient seed supply & 28 & 14.0 \\
Poor telephony network & 87 & 43.5 \\
Low level of awareness among farmers, & 112 & 56.0 \\
Cumbersome procedure of getting approval from cellulants & 88 & 44.0 \\
Low density coverage of agro-dealers & 65 & 32.5 \\
Incompatibility of e-wallet with other technologies & 180 & 90 \\
Inability to operate mobile phone & 81 & 40.5 \\
High rate of illiteracy & 127 & 63.5 \\
\hline
\end{tabular}

shortage has not been fully resolved. It could be said that the private sectors are not ripe enough to take total control of the fertilizer distribution strategies of the nation. This calls for capacity building of agro dealers in fertilizer acquisition and distribution strategies.

Poor extension services, lack of market information on prices, limited access to credit facilities, inadequate supply were stated among the constraints to effective fertilizer distribution in Nigeria (IFPRI, 2010). The low density coverage of agro dealers might result from insufficient information in getting more agro dealers involved in training and registration in the program, poor telephony network is a major challenge of some of the telephone subscribers in Nigeria. The coverage of some of the networks are restricted to particular areas hence most farms might have limited network coverage. The cumbersome procedure of getting approval from cellulants might be a teething problem which is common to most projects and would be overcome as the project continues. This cumbersome procedure is similar to one of the major challenges of obtaining credit facilities by farmers from commercial banks in Nigeria.

\section{SUMMARY AND CONCLUSION}

This study revealed that most of the farmers that participated in the scheme were young, mostly male, married with large household sizes but low educational status. Most of them had farming as their primary occupation with long years of experiences. Crops produced were cassava, yam, maize, rice, vegetables, plantain and cocoyam. The major source of land for production was through inheritance and rent. The participants in the scheme were mostly small scale farmers.

All the respondents were aware of the growth enhancement scheme with extension agents, co-op societies, radio and friends as their major sources of information. All of them possess mobile phones directly or indirectly and have registered with Growth Enhancement Programme(GEP), some in 2011 and others in 2012. They all attend GEP training consequently, some benefitted from the subsidized improved maize seed and two bags of fertilizers each while others benefitted from improved seed rice seeds. Not all the respondents have access to fertilizer. The number of time delivery such benefit $s$ varies from the least being one time and the highest being three times.

Benefits being derived from the use of $e$ - wallet approach by the respondents include; quickened accessibility to improve seeds, access to fertilizer and subsidized farm input. Farmers indicated the e-wallet approaches have actually increased their output and quality of rice/maize produced but have less impact on their farm size. The challenges of the scheme include low level of awareness among farmers, insufficient fertilizer supply: cumbersome procedure of getting approval from cellulants, poor telephone network and low density coverage of agro dealers. A huge portion of the respondent has not benefitted from agricultural intervention programs before.

\section{RECOMMENDATIONS}

For the sustainability of e-wallet approach, the study recommends the following;

Since the farmers used mostly interpersonal communication, more extension agents should be involved in the scheme.

Radio and television broadcast of the program in various Nigerian local languages should be increased most especially before the onset of each program

The training program should be intensified to address the challenges of getting approval from cellulant.

Also, an operational handbook/manual on e-wallet approach should be developed and distributed to all the stakeholders

There is the need for the government to sensitize mobile network owners in Nigeria to widen their network services coverage to improve phone use in rural areas.

Agro dealers should make proper arrangement before production season starts with fertilizer company in order to guide against failure There is the need to review the bureaucratic verification process to avoid time wastage 
The government should embrace participatory approach in project evaluation after 5 years and tackle all the teething problems.

To sustain this laudable effort of government, the planning of food production should be a conscious collaboration among several groups, namely state government, private enterprises, training and research institutions and non-governmental organization.

There should be an enabling legislation backing the Agricultural Transformation Agenda and Growth Enhancement Scheme.

The traditional land tenure system that hinders the acquisition of land for agriculture should be reviewed.

There should be continuity of the programme without misplacing its priority.

Also, policies that would increase the productivity of small holder farmers should be given adequate attention.

\section{REFERENCE}

Abubakar BY (2010). The Role of Research and Development in Attainment of Food Security in Nigeria. A paper presented at the National Agriculture Show, held at National Agricultural Foundation of Nigeria conference hall, Nassarawa State on 13-14 October.

Adesina A (2013). Honourable Minister of Agriculture and Rural Development, Federal Republic of Nigeria, Governor from Nigeria

Akinwumi A. 2012. Investing in Nigeria's Agricultural Value Chains. A paper presented to the Bank of Industry Nigerian Investment Forum, London, July 30.

Assessment of food insecurity status and government interventions in Nigeria. The challenges and prospect in the next decade. Proceedings of the $46^{\text {th }}$ annual conference of the agric society of Nigeria.

Azubuike G (2008). Nigerian Food Insecurity as a Time bomb. Retrieved online at http:/allafrica.com.stories/201203110293.html.A.E.Obayelu@A.O.Ob ayelu.2012

Bryce J, Boschi-Pinto C, Shibuya K, Blake RE (2005). WHO estimate of the causes of Death in children, Lancet

Businessday News January 21, 2013: Cell phones for Nigerian farmers, http://www.

businessdayonline.com/NG/index.php/analysis/commentary/50442cellphones-fornigerian-farmers

Channelsweb January 15 (2013): Minister insists on buying GSM Phones for Farmers, http://www.youtube.com/watch?v=GlrdNhT5aZ0

Consultative Group on International Agricultural Research (1997) Information Needs of Small Scale Farmers in Africa. The Nigerian Example. Vol 4 No $3 . \quad$ Available on www.worldbank.org/ht//cgiar/newsletter/june97/9cgnews.html Emmanuel Acha,
nigerianobservernews.com/07102013/features/features4.html.

Federal Ministry of Agriculture and Rural Development (FMARD) (2009). National Food Security Programme, Federal Republic of Nigeria.

Federal Ministry of Agriculture and Water Resources (FMAWR). 2008. National Food Security Programme, Federal Republic of Nigeria.

National Bureau of Economic Research (2014). Global Demographic Change Dimensions and Economic Significance. NIBER working paper series. Available http://www.nber.org/papers/w1087
National Bureau of Statistics (2012). Review of the Nigerian Economy in 2011 and Economic Outlook for 2012-2014, National Bureau of Statistics

National Population Commission (2014) Nigerian Unemployment Rate. Nigerian Unemployment Rate. Available onhttp://www.tradingeconomics.com/nigeria/unemployment-rate

News Agency of Nigeria, December 12, 2012: 2,711 Lagos Farmers Benefit from Growth Enhancement Support Scheme,http://www.nannewsngr.com/section/agriculture/2711-lagosfarmers benefit-from-growth-enhancement-scheme

News Agency of Nigeria, October 07, 2012: Growth Enhancement Support Scheme: Sen. Adamu commends FG, http://nanngronline.com/section/agriculture/growthenhancement support-scheme-sen-adamu-commends-fg.

NPC (National Population Commission) 2006Population Census of the Federal Republic ofNigeria. Analytical Report at the National PopulationCommission, Abuja, Nigeria.

O. A. Osinowo, 2012. Agricultural Transportation in a Deregulated Economy: the role of livestock subsector. Proceedings of the $46^{\text {th }}$ Annual Conference of Agricultural Society of Nigeria, head at Bayero University, kano.

Punch Newspaper, December 28, 2012: Growth Enhancement Support Scheme savedAgric Sector, http://www.punchng.com/business/industry/growthenhancementsupport- scheme-saved-agric-sector-adesina/ Thai National Committee on Irrigation and Drainage Thailand (THAICIDnd) http://www.icid.org/v thailand.pdf

Vanguard Newspaper, January 15, 2013: Nigeria: No going back For Farmers,http://www.vanguardngr.com/2013/01/no-going-back-oncell-phonesfor-farmers-minister/

World Bank (2013). Nigerian/World Bank Data. Trading Economics. Available on http://www.tradingeconomics.com/nigeria/indicators-wb 